\title{
Calcium anacardate as growth promoter for piglets at the nursery phase
}

\author{
Amanda Veruska Silva de Matos $^{(1)}$, Pedro Henrique Watanabe(1), Ednardo Rodrigues Freitas ${ }^{(1)}$, \\ Kassia Moreira Santos ${ }^{(1)}$, Lina Raquel Santos Araújo(1), Rafael Carlos Nepomuceno(1), \\ Alini Mari Vieira ${ }^{(1)}$ and Eloisa Helena Mendes Vieira ${ }^{(1)}$
}

(1)Universidade Federal do Ceará, Departamento de Zootecnia, Campus do Pici, Avenida Mister Hull, no 2.977, Caixa Postal 12.168, CEP 60021-970 Fortaleza, CE, Brazil. E-mail: amandaveruskasm@hotmail.com, pedrowatanabe@ufc.br, ednardo@ufc.br, kmszootecnia@gmail.com, linaaraujo@gmail.com,rafael@zootecnista.com.br, alini.mari@hotmail.com, ello.mendes@hotmail.com

\begin{abstract}
The objective of this work was to evaluate the effects of the dietary inclusion of calcium anacardate on the performance, diarrhea incidence, blood parameters, intestinal morphometry, and $\mathrm{pH}$ of gastrointestinal contents in piglets from 21 to 42 days of age. Sixty weaned Topigs piglets, with initial weight of $6.049 \pm 0.311$ $\mathrm{kg}$, were distributed in the following treatments: diet with or without antibiotic growth promoter (zinc bacitracin) and diets supplemented with increasing levels of calcium anacardate $(0.4,0.8$, and $1.2 \%)$, with six replicates and two animals per experimental unit. No differences in performance ( 21 to 42 days of age), blood parameters, and villus height:crypt depth ratio were found between piglets fed diets containing calcium anacardate or antibiotic growth promoter. The replacement of the antibiotic growth promoter zinc bacitracin by calcium anacardate results in similar performance in piglets from 21 to 42 days of age, without changes in blood parameters and in the villus height:crypt depth ratio. The dietary inclusion of calcium anacardate does not decrease diarrhea incidence compared with the antibiotic zinc bacitracin.
\end{abstract}

Index terms: anacardic acid, intestinal morphometry, organic acids, phenolic compounds, post-weaning, zinc bacitracin.

\section{Anacardato de cálcio como promotor de crescimento para leitões na fase de creche}

Resumo - O objetivo deste trabalho foi avaliar os efeitos da inclusão do anacardato de cálcio em rações para leitões, dos 21 aos 42 dias de idade, sobre desempenho, ocorrência de diarreia, parâmetros sanguíneos, morfometria intestinal e pH dos conteúdos gastrintestinais. Foram avaliados 60 leitões desmamados da linhagem comercial Topigs, com peso inicial de $6,049 \pm 0,311 \mathrm{~kg}$, distribuídos entre os seguintes tratamentos: rações com ou sem antibiótico promotor de crescimento (bacitracina de zinco) e rações contendo doses crescentes de anacardato de cálcio $(0,4,0,8$ e 1,2\%), com seis repetições e dois animais por unidade experimental. Não foram observadas diferenças no desempenho ( 21 a 42 dias de idade), nos parâmetros sanguíneos e na relação altura de vilosidade/profundidade de cripta entre leitões que receberam ração contendo anacardato de cálcio ou antibiótico promotor de crescimento. A substituição de antibiótico promotor de crescimento bacitracina de zinco pelo anacardato de cálcio resulta em desempenho semelhante de leitões dos 21 aos 42 dias de idade, e não altera os parâmetros sanguíneos e a relação altura de vilosidade/profundidade de cripta. A inclusão de anacardato de cálcio na ração não diminui a ocorrência de diarreia em comparação ao antibiótico bacitracina de zinco.

Termos para indexação: ácido anacárdico, morfometria intestinal, ácidos orgânicos, compostos fenólicos, pós-desmame, bacitracina de zinco.

\section{Introduction}

Global pig farms have undergone major changes mainly affected by specific markets and their demands towards several aspects in pig production, such as the restriction or total ban on the use of antibiotic growth promoters in animal feed. However, the absence of these promoters particularly affects the animals more susceptible to enteric diseases, such as nursery piglets. This animal category has an insufficient production of digestive enzymes, leading to the low utilization of nutrients, which may become substrates for pathogenic bacteria (Lallès, 2008). 
Considering this scenario, several substances have been studied aiming at replacing antibiotic growth promoters in piglet diets. Therefore, a deeper understanding about the mode of action and inclusion level of each substitute is essential. Among these substances, organic acids are highlighted, which mode of action involves the decrease in gastric $\mathrm{pH}$, facilitating protein digestion and the absorption of amino acids and other nutrients in the intestine, besides acting as a bactericide by reducing the bacteria internal $\mathrm{pH}$ due to its dissociation (Chiquieri et al., 2009). Therefore, the use of organic acids in the diet seeks to inhibit the pathogenic intestinal microflora, as well as to reduce its toxic metabolites (Suiryanrayna \& Ramana, 2015). These processes help to create a favorable intestinal environment for beneficial microorganisms within the animal's digestive tract (Partanen \& Mroz, 1999) and may reduce the frequency of post-weaning diarrhea, leading to an improvement in piglet performance, especially at the beginning of the nursery phase (Li et al., 2008; Papatsiros et al., 2011).

Among the organic acids, anacardic acid, a phenolic compound found in different parts of the cashew tree (Anacardium occidentale L.) and mainly in the cashew nut, has been widely studied. Reports in the literature indicate that this compound has several biological activities (Hamad \& Mubofu, 2015), with emphasis on the selective inhibitory activity against pathogenic microorganisms (Muroi \& Kubo, 1996; Narasimhan et al., 2008; Achanath et al., 2010; Hollands et al., 2016), including enteric bacteria of the genus Shigella, Salmonella, and Escherichia coli (Eslami et al., 2014).

For organic acids to exert their bactericidal effects, they must be non-dissociated to allow the passive diffusion through the bacterial cell wall, where they can dissociate and reduce cell $\mathrm{pH}$, denaturing bacterial DNA (Braz et al., 2011). Anacardic acid can be extracted from the precipitation of cashew nut shell liquid with calcium hydroxide, forming calcium anacardate (Paramashivappa et al., 2001). However, the feasibility and the effects of calcium anacardate on animal performance or intestinal health in nursery piglets are not yet known.

The objective of this work was to evaluate the effects of the dietary inclusion of calcium anacardate on the performance, diarrhea incidence, blood parameters, intestinal morphometry, and $\mathrm{pH}$ of gastrointestinal contents in piglets from 21 to 42 days of age.

\section{Materials and Methods}

The study was conducted in alignment with the procedures of the ethics committee on animal use of Universidade Federal do Ceará, under the protocol No. 113/2014.

Prior to the trial, calcium anacardate was extracted from the cashew nut shell liquid. The cashew nuts used came from the same crop of the Gigante agronomic variety. The cashew nut shell liquid was obtained by heating the nuts in the oven at $120^{\circ} \mathrm{C}$ for $70 \mathrm{~min}$ (Trevisan et al., 2006). Calcium anacardate was produced from the reaction between anacardic acid, present in cashew nut shell liquid, with calcium hydroxide, forming a calcium salt, according to the method described by Paramashivappa et al. (2001), with modifications.

The trial was carried out in the pig research center of the Department of Animal Sciences of Universidade Federal do Ceará, during 22 days. Sixty castrated male piglets weaned at 21 days of age were distributed into five treatments with six replicates, in a randomized complete block design, considering a cage with two animals as the experimental unit. Piglets were placed in metal cages with plastic mesh floors $(1.0 \times 2.0 \mathrm{~m})$ suspended $50 \mathrm{~cm}$ above of the floor. During the experimental period, the average shed temperature was $28.5^{\circ} \mathrm{C}$ and the relative humidity was $64 \%$. The treatments were: diet without growth promoter, as a negative control; diet supplemented with antibiotic growth promoter (50 ppm zinc bacitracin), as a positive control; diet supplemented with $0.4 \%$ calcium anacardate; diet supplemented with $0.8 \%$ calcium anacardate; and diet supplemented with $1.2 \%$ calcium anacardate. Zinc bacitracin or calcium anacardate were added to the diet by replacing the kaolin inert ingredient.

The criterion adopted for blocking was the mean initial weight, of $5.828 \pm 0.185$ and $6.480 \pm 0.305 \mathrm{~kg}$, for light and heavy blocks, respectively.

The experimental diets were formulated for phases I ( 21 to 32 days of age) and II (33 to 42 days of age), considering the feed composition and the nutritional requirements for nursery piglets according to Rostagno et al. (2011); all diets were isonutritive and isoenergetic for each phase (Table 1). The evaluated variables of animal performance were daily feed intake, daily weight gain, and feed conversion. The daily feed intake was calculated as the difference between feed offered and leftover, divided by the number of days in each phase. 
Daily weight gain was calculated as the difference between the final weight and the initial weight of the piglets, divided by the number of days in each phase. The feed conversion was calculated as a function of the relationship between the total feed intake and the total weight gain in each phase during the trial.

A single observer assessed diarrhea incidence twice a day, at 8:00 a.m. and 4:00 p.m., throughout the experimental period. Through visual analysis, the feces of the each replicate of piglets were classified according to the following criteria: score 0, feces with solid consistency; score 1, pasty feces; score 2, semiliquid diarrhea; and score 3, liquid diarrhea. Diarrhea cases were considered when the fecal score

Table 1. Nutritional and percentage composition of experimental diets for piglets during stage I and stage II.

\begin{tabular}{lcc}
\hline Ingredient (\%) & $\begin{array}{c}\text { Stage I } \\
\text { (21 to 32 days) }\end{array}$ & $\begin{array}{c}\text { Stage II } \\
\text { (33 to 42 days) }\end{array}$ \\
\hline Corn grain & 48.80 & 50.66 \\
Soybean meal & 25.35 & 27.89 \\
Whole milk powder & 15.00 & 10.00 \\
Sugar & 5.00 & 5.00 \\
Soybean oil & - & 1.08 \\
Dicalcium phosphate & 1.96 & 1.92 \\
Calcitic limestone & 0.82 & 0.63 \\
Salt & 0.50 & 0.41 \\
Mineral and vitamin supplement ${ }^{(1)}$ & 0.50 & 0.50 \\
BHT & 0.01 & 0.01 \\
L-lysine HCL (78.5\%) & 0.59 & 0.49 \\
DL-methionine (99.0\%) & 0.24 & 0.18 \\
Kaolin & 1.20 & 1.20 \\
\hline Nutritional composition & & \\
Metabolizable energy (Mcal kg ${ }^{-1}$ ) & 3.39 & 3.37 \\
Crude protein (\%) & 20.00 & 20.00 \\
Available phosphorus (\%) & 0.45 & 0.45 \\
Calcium (\%) & 0.90 & 0.82 \\
Digestible lysine (\%) & 1.45 & 1.35 \\
Digestible methionine + cystine (\%) & 0.81 & 0.74 \\
Sodium (\%) & 0.28 & 0.23 \\
\hline
\end{tabular}

(1)The premix supplied the following per kilogram of diet: 1,500,000 IU vitamin A; 450,000 IU vitamin D3; $22.50 \mathrm{mg}$ biotin; $68 \mathrm{mg}$ choline; 7,500 $\mathrm{mg}$ niacin; 4,500 mg calcium pantothenate; $5,000 \mathrm{mg}$ vitamin $\mathrm{B} 12 ; 1,300$ $\mathrm{mg}$ vitamin $\mathrm{B} 2 ; 7,500 \mathrm{mg}$ vitamin $\mathrm{E} ; 1,500 \mathrm{mg}$ vitamin $\mathrm{K} 3 ; 12.5 \mathrm{~g}$ iron; $5,250 \mathrm{mg}$ copper; $8,750 \mathrm{mg}$ manganese; $26.25 \mathrm{~g}$ zinc; $350 \mathrm{mg}$ iodine; and $75 \mathrm{mg}$ selenium. was 2 or 3. The diarrhea incidence rates for each treatment were calculated (Silva et al., 2010).

One piglet per cage at 42 days of age was randomly selected, and blood samples were collected from the jugular vein to evaluate the following blood parameters: hemogram, leukogram, and serum proteins. For hemograms and leukograms, $2 \mathrm{~mL}$ of blood were collected in tubes containing the anticoagulant ethylenediaminetetraacetic acid (EDTA). The concentrations of red blood cells, hemoglobin, hematocrit, mean corpuscular volume, and mean corpuscular hemoglobin concentration were determined using the hemogram. Differential count of leukocytes was performed, calculating the percentages of lymphocytes, eosinophils, segmented neutrophils, monocytes, and platelets. For the evaluation of serum proteins, $4 \mathrm{~mL}$ of blood were collected in tubes without anticoagulant and were centrifuged. Using the resulting serum, the concentrations of total serum proteins, albumin, and globulin (Arantes et al., 2007) were evaluated.

At 42 days of age, one animal from each replicate was slaughtered to evaluate the $\mathrm{pHs}$ of the stomach, intestinal and cecal contents, as well as the morphological characteristics of the duodenum and jejunum. Immediately after slaughter, the stomach, small intestine, and cecum contents were removed and placed separately in plastic containers for $\mathrm{pH}$ determination using the HI99163 digital $\mathrm{pH}$ meter (Hanna Instruments Brasil, Barueri, SP, Brazil). Regarding the morphological characteristics of the intestine, 3-cm long sections of the duodenum and jejunum were collected. The duodenum fragment was removed $15 \mathrm{~cm}$ from the insertion of the stomach and the jejunum fragment was collected $95 \mathrm{~cm}$ from the ileocecal junction, stretched along the mesenteric border on a small piece of cardboard with pins and stored in $10 \%$ formaldehyde $(\mathrm{v} / \mathrm{v})$. The tissue slides were embedded in paraffin and stained with hematoxylin and eosin (Behmer et al., 1976). Morphometric analyzes of villus height, crypt depth, and the villus height:crypt depth ratio of the intestinal epithelium were analyzed with the DM500 light microscope (Leica Microsystems GmbH, Wetzlar, Germany) with a 10x objective magnification, using the Leica Qwin image analysis system (Leica, Microsystems $\mathrm{GmbH}$, Wetzlar, Germany) connected to the microscope.

Pesq. agropec. bras., Brasília, v.52, n.12, p.1253-1260, dez. 2017 DOI: 10.1590/S0100-204X2017001200014 
Data were subjected to the analysis of variance using the general linear model procedure of the SAS software, version 8.1 (SAS Institute, Inc., Cary, NC, USA). Data on diarrhea incidence were transformed by the $y=\arcsin [(\mathrm{p} / 100)]^{0.5}$ function as recommended by Barbin (2003). After checking for normality of the residues, the means were compared by the StudentNewman-Keuls's test, at 5\% probability.

\section{Results and Discussion}

The inclusion of antibiotic growth promoter and calcium anacardate had no effect on daily feed intake and feed conversion in piglets from 21 to 32 days of age (Table 2). However, piglets fed a diet without growth promoter had lower weight gain than those fed diets with antibiotic or calcium anacardate. From 21 to 42 days of age, although antibiotic and calcium anacardate inclusions had no effect on feed intake, piglets receiving antibiotics had greater weight gain compared with animals fed diets without growth promoter, but did not differ from piglets supplemented with calcium anacardate. Piglets fed diets containing antibiotic growth promoter or calcium anacardate had better feed conversion than piglets fed diet without growth promoter. However, the inclusion of organic acids resulted in lower weight gain and worse feed conversion in piglets when compared with the use of conventional growth promoters (Walsh et al., 2014).

The variability of results may be a consequence of aspects that decrease the effectiveness of organic acids, such as the use of ingredients with higher buffer capacity in the digesta (Papatsiros et al., 2012) or the dietary use of less digestible protein fractions (Kommera et al., 2006; Halas et al., 2007), which shows the need for a better understanding of the use of dietary organic acids. However, some ingredients may also favor or impair the effect of organic acids, such as dairy products that are high in lactose (Suiryanrayna \& Ramana, 2015) or microminerals such as zinc and copper at high levels (Boas et al., 2016). There was no effect of growth promoters on piglet performance due to the absence of challenges to the animal's health. Therefore, the difference observed between the animals fed with antibiotic or calcium anacardate and those fed no growth promoter showed the positive effect of these additives in conditions comparable to those found in the farms.

Regarding the diarrhea incidence, animals fed a diet with antibiotics had lower diarrhea incidence than piglets from the other treatments (Table 3). Similarly, Oetting et al. (2006) reported reduced diarrhea incidence in piglets fed growth promoters (zinc bacitracin, olaquindox, and colistin), compared with animals fed a diet without growth promoter or herbal extracts of eugenol and carvacrol. Several factors are mainly responsible for post-weaning diarrhea, such as the colonization of the epithelial surface by pathogens, morpho-histological changes due to weaning stress, and the presence of undigested and non-absorbed feed residues that may act as substrates for fermentation by the intestinal microbiota, increasing the production of lactic acid and volatile fatty acids. In turn, the combination of these substrates, feed residues, and

Table 2. Daily feed intake (DFI), daily weight gain (DWG), and feed conversion (FC) of piglets fed diets with or without the antibiotic zinc bacitracin, and with different inclusion levels of calcium anacardate during stage I and stage $\mathrm{II}^{(1)}$.

\begin{tabular}{|c|c|c|c|c|c|c|c|}
\hline \multirow[t]{2}{*}{ Variable } & \multirow{2}{*}{$\begin{array}{l}\text { Negative } \\
\text { control }^{(2)}\end{array}$} & \multirow{2}{*}{$\begin{array}{l}\text { Positive } \\
\text { control }^{(3)}\end{array}$} & \multicolumn{3}{|c|}{ Calcium anacardate $(\%)$} & \multirow{2}{*}{$\begin{array}{l}\text { Coefficient of } \\
\text { variation (\%) }\end{array}$} & \multirow[t]{2}{*}{ p-value } \\
\hline & & & 0.4 & 0.8 & 1.2 & & \\
\hline & \multicolumn{7}{|c|}{ Stage I (21 to 32 days) } \\
\hline DFI (g) & 160.74 & 175.35 & 168.36 & 183.88 & 172.58 & 11.03 & 0.256 \\
\hline DWG (g) & 110.09B & $142.82 \mathrm{~A}$ & $145.15 \mathrm{~A}$ & $131.64 \mathrm{~A}$ & $140.09 \mathrm{~A}$ & 20.79 & 0.024 \\
\hline \multirow[t]{2}{*}{$\mathrm{FC}$} & 1.46 & 1.25 & 1.16 & 1.39 & 1.23 & 13.88 & 0.054 \\
\hline & \multicolumn{7}{|c|}{ Stage II (21 to 42 days) } \\
\hline DFI (g) & 256.31 & 283.02 & 278.83 & 284.16 & 275.18 & 12.48 & 0.698 \\
\hline DWG (g) & 142.79B & $194.33 \mathrm{~A}$ & $173.08 \mathrm{AB}$ & $177.11 \mathrm{AB}$ & $172.13 \mathrm{AB}$ & 16.41 & 0.009 \\
\hline $\mathrm{FC}$ & $1.81 \mathrm{~A}$ & $1.48 \mathrm{~B}$ & $1.61 \mathrm{~B}$ & $1.60 \mathrm{~B}$ & $1.60 \mathrm{~B}$ & 6.29 & 0.001 \\
\hline
\end{tabular}

(1)Means followed by equal letters, uppercase in the rows, do not differ by Student-Newman-Keuls's test, at 5\% probability. ${ }^{(2)}$ Without growth promoter. ${ }^{(3)}$ Control with $50 \mathrm{ppm}$ zinc bacitracin growth promoter. 
ions (sodium, potassium, and chloride) increase the osmotic potential of the intestinal contents. Therefore, the process of water reabsorption is hampered and an inflow of water into the intestinal lumen occurs, triggering diarrhea (Utiyama et al., 2006). In view of the complex etiology that involves the post-weaning diarrhea syndrome, despite the incidence of diarrhea, piglets fed a diet with calcium anacardate did not have impaired performance as observed in piglets fed diet without growth promoter.
No effect of antibiotic growth promoter and calcium anacardate was observed on blood parameters, except for the red blood cell and globulin concentrations (Table 4). Higher concentration of red blood cells was found in piglets receiving antibiotics and 0.8 and $1.2 \%$ of calcium anacardate in the diet, with values within normal limits (Kaneko, 1989). Although the lowest concentration of red blood cells may be associated with the prevalence of anemia in the piglets during suckling and in the nursery stage (Bhattarai \& Nielsen, 2015), due to the low turnover rate of

Table 3. Mean incidence rate and transformed means (TM) of diarrhea in piglets from 21 to 42 days of age fed diets with or without the antibiotic zinc bacitracin and different inclusion levels of calcium anacardate ${ }^{(1)}$.

\begin{tabular}{|c|c|c|c|c|c|c|c|}
\hline \multirow{2}{*}{$\begin{array}{l}\text { Fecal } \\
\text { consistency }\end{array}$} & \multirow{2}{*}{$\begin{array}{l}\text { Negative } \\
\text { control }^{(2)}\end{array}$} & \multirow{2}{*}{$\begin{array}{l}\text { Positive } \\
\text { control }^{(3)}\end{array}$} & \multicolumn{3}{|c|}{ Calcium anacardate $(\%)$} & \multirow{2}{*}{$\begin{array}{l}\text { Coefficient of } \\
\text { variation }(\%)\end{array}$} & \multirow[t]{2}{*}{ p-value } \\
\hline & & & 0.4 & 0.8 & 1.2 & & \\
\hline Incidence rate $(\%)$ & 26.01 & 14.07 & 30.98 & 27.85 & 24.58 & - & - \\
\hline Transformed means & $0.54 \mathrm{~A}$ & $0.38 \mathrm{~B}$ & $0.59 \mathrm{~A}$ & $0.56 \mathrm{~A}$ & $0.51 \mathrm{~A}$ & 6.85 & 0.011 \\
\hline
\end{tabular}

${ }^{(1)}$ Means followed by equal letters do not differ by Student-Newman-Keuls's test, at 5\% probability. ${ }^{(2)}$ Without growth promoter. ${ }^{(3)}$ Control with 50 ppm zinc bacitracin growth promoter.

Table 4. Hemogram, leukogram, serum proteins, and $\mathrm{pHs}$ of stomach, small intestine, and cecum of 42-day old piglets fed diets with or without the antibiotic zinc bacitracin and different inclusion levels of calcium anacardate.

\begin{tabular}{|c|c|c|c|c|c|c|c|}
\hline \multirow[t]{2}{*}{ Variable $^{(2)}$} & \multirow{2}{*}{$\begin{array}{l}\text { Negative } \\
\text { control }^{(3)}\end{array}$} & \multirow{2}{*}{$\begin{array}{l}\text { Positive } \\
\text { control }^{(4)}\end{array}$} & \multicolumn{3}{|c|}{ Calcium anacardate $(\%)$} & \multirow{2}{*}{$\begin{array}{l}\text { Coefficient of } \\
\text { variation (\%) }\end{array}$} & \multirow[t]{2}{*}{ p-value } \\
\hline & & & 0.4 & 0.8 & 1.2 & & \\
\hline $\mathrm{RBC}(\mu \mathrm{L})$ & $6.38^{\mathrm{B}}$ & $7.89^{\mathrm{A}}$ & $5.87^{\mathrm{B}}$ & $7.81^{\mathrm{A}}$ & $7.85^{\mathrm{A}}$ & 11.00 & 0.001 \\
\hline Hemoglobin $\left(\mathrm{g} \mathrm{dL}^{-1}\right)$ & 12.38 & 13.47 & 12.10 & 12.32 & 12.34 & 10.14 & 0.478 \\
\hline Hematocrit (\%) & 37.16 & 40.50 & 35.60 & 36.20 & 36.40 & 10.24 & 0.304 \\
\hline $\operatorname{MCV}\left(\mu \mathrm{m}^{3}\right)$ & 59.00 & 60.65 & 60.80 & 57.02 & 58.06 & 3.74 & 0.352 \\
\hline $\mathrm{MCHC}(\%)$ & 33.25 & 33.50 & 33.96 & 33.96 & 33.72 & 1.21 & 0.055 \\
\hline Leukocytes (\%) & 13.38 & 17.75 & 15.44 & 17.84 & 16.24 & 20.68 & 0.233 \\
\hline Segmented (\%) & 55.83 & 48.00 & 58.40 & 58.20 & 54.00 & 11.69 & 0.106 \\
\hline Lymphocytes (\%) & 37.50 & 41.75 & 37.60 & 33.00 & 38.00 & 19.24 & 0.471 \\
\hline Eosinophils (\%) & 2.16 & 1.00 & 1.40 & 1.40 & 1.40 & 86.21 & 0.695 \\
\hline Monocytes (\%) & 7.00 & 7.60 & 7.60 & 7.40 & 6.60 & 37.69 & 0.359 \\
\hline Platelets $(\mu \mathrm{L})$ & 556.67 & 648.67 & 414.00 & 476.00 & 488.00 & 26.35 & 0.111 \\
\hline Protein $\left(\mathrm{g} \mathrm{dL}^{-1}\right)$ & 5.43 & 4.80 & 5.12 & 5.36 & 5.64 & 10.16 & 0.167 \\
\hline Albumin $\left(\mathrm{g} \mathrm{dL}^{-1}\right)$ & 2.95 & 2.86 & 2.92 & 2.88 & 2.92 & 21.86 & 0.003 \\
\hline Globulin $\left(\mathrm{g} \mathrm{dL}^{-1}\right)$ & $3.30 \mathrm{~A}$ & $2.48 \mathrm{~B}$ & $2.95 \mathrm{~A}$ & $2.78 \mathrm{AB}$ & $2.72 \mathrm{AB}$ & 10.33 & 0.001 \\
\hline Stomach $\mathrm{pH}$ & 3.14 & 3.28 & 3.63 & 3.54 & 3.67 & 28.71 & 0.897 \\
\hline Small intestine $\mathrm{pH}$ & 5.86 & 6.07 & 6.14 & 6.37 & 6.67 & 8.00 & 0.037 \\
\hline Cecal pH & $5.88^{\mathrm{A}}$ & $5.23^{\mathrm{B}}$ & $5.38^{\mathrm{B}}$ & $5.38^{\mathrm{B}}$ & $5.36^{\mathrm{B}}$ & 5.89 & 0.015 \\
\hline
\end{tabular}

${ }^{(1)}$ Means followed by equal letters do not differ by Student-Newman-Keuls's test, at $5 \%$ probability. ${ }^{(2)} \mathrm{RBC}$, red blood cells; MCV, mean corpuscular volume; and MCHC, mean corpuscular hemoglobin concentration. ${ }^{(3)}$ Without growth promoter. ${ }^{(4)}$ Control with 50 ppm zinc bacitracin growth promoter. 
the erythrocyte cell (85 days), values related to the quantification of these cells are not sensitive indicators of erythropoiesis. Therefore, the observed difference in red blood cells concentration may be associated with transient polycythemia, caused by the contraction of the spleen, which releases additional erythrocytes into the circulation (Soto et al., 2008).

For globulin, higher values were found in piglets fed a diet without growth promoter and with $0.4 \%$ calcium anacardate, whereas lower values were obtained in piglets receiving antibiotic growth promoter, which did not differ from piglets supplemented with 0.8 and $1.2 \%$ calcium anacardate. According to Robles-Huaynate et al. (2014), globulin concentrations tend to increase due to inflammatory or infectious diseases and, in this sense, the highest values observed in piglets fed diet without growth promoter confirm the lowest weight gain of the animals from 21 to 32 days of age.

The pHs of the stomach and small intestine were not affected by the dietary inclusion of antibiotic or calcium anacardate (Table 4). Although the mode of action of some organic acids consists in reducing digesta $\mathrm{pH}$, the effectiveness of these substances as antimicrobials comprises the maintenance of its nondissociated form (Partanen \& Mroz, 1999), which allows the diffusion through the membrane of the microorganisms and its dissociation, affecting the enzymatic system and the transport of nutrients. Since anacardic acid is derived from salicylates (Sung et al., 2008), which $\mathrm{pKa}$ is between 3.0 and $3.5, \mathrm{pH}$ values in the stomach of piglets would indicate a dissociation of $50 \%$ into the gastric compartment.

The cecal $\mathrm{pH}$ values were higher in animals fed no growth promoter. By comparing the effect of the growth-promoting antibiotic colistin sulphate with acidifiers in a mixture, Braz et al. (2011) observed that the antibiotic also resulted in increased cecal $\mathrm{pH}$. Pedroso et al. (2005), evaluating the supplementation with the growth-promoting antibiotics zinc bacitracin, colistin, olaquindox, and herbal extracts of clove, oregano and thyme, reported higher abundance of bacteria in pigs fed a diet without growth promoters. In this context, due to its antimicrobial action, the growth promoter, as well as calcium anacardate, may result in a lower microbial population, which would result in lower production of short-chain fatty acids that would reduce cecal $\mathrm{pH}$.

Regarding the analysis of intestinal morphometry, no effect of antibiotic growth promoter or calcium anacardate was observed in the jejunum (Table 5). In the duodenum, lower villus height was verified in piglets fed a diet without growth promoter, compared animals fed a diet containing 0.4 and $1.2 \%$ with calcium anacardate, but not differing from piglets supplemented with antibiotic growth promoter and $0.8 \%$ calcium anacardate. The piglets fed a diet without growth promoter and $0.4 \%$ calcium anacardate had higher crypt depth than those receiving antibiotic, but did not differ from piglets supplemented with 0.8 and $1.2 \%$ calcium anacardate. Consequently, a higher villus height:crypt depth ratio was observed in piglets fed diets containing antibiotic growth promoter or calcium anacardate. The reduction in villus height can be caused by the rate of cell loss from the villi due to the beginning of solid feed intake, low feed intake, bacterial toxins, and bacterial adhesion to enterocytes (Tucci et al., 2011). In turn, the rise in crypt depth occurs due to increased cell production to ensure an

Table 5. Villus height, crypt depth, and villus height:crypt depth ratio of 42-day old piglets fed diets with or without antibiotic zinc bacitracin and different inclusion levels of calcium anacardate ${ }^{(1)}$.

\begin{tabular}{lccccccc}
\hline Variable & $\begin{array}{c}\text { Negative } \\
\text { control }^{(2)}\end{array}$ & $\begin{array}{c}\text { Positive } \\
\text { control }^{(3)}\end{array}$ & \multicolumn{3}{c}{ Calcium anacardate (\%) } & Coefficient of \\
variation $(\%)$
\end{tabular}

${ }^{(1)}$ Means followed by equal letters do not differ by Student-Newman-Keuls's test, at $5 \%$ probability. ${ }^{(2)}$ Without growth promoter. ${ }^{(3)} \mathrm{Control}$ with 50 ppm zinc bacitracin growth promoter. 
adequate cell turnover rate and cell replacement from the apical region of the villi. It may be detrimental to the animal because it increases energy losses with cell turnover (Oetting et al., 2006), as well as the presence of immature cells in the villi, which may lead to a higher diarrhea incidence.

\section{Conclusions}

1. The replacement of the antibiotic growth promoter zinc bacitracin by calcium anacardate results in similar performance in piglets from 21 to 42 days of age, and does not alter blood parameters and the villus height:crypt depth ratio.

2. Calcium anacardate as a growth promoter does not decrease diarrhea incidence in piglets from 21 to 42 days of age.

\section{References}

ACHANATH, R.; SRINIVAS, M.; RAMADOSS, C.S. Antimicrobial derivatives of anacardic acid and process for preparing the same. Int. C07C65/01, C07C237/28, C07C229/54, A01N37/18. US8338638 B2. Jan. 21 2010. Available at: <http:// www.freepatentsonline.com/y2010/0016630.html $>$. Accessed on: Jan. 102015.

ARANTES, V.M.; THOMAZ, M.C.; KRONKA, R.N.; MALHEIROS, E.B.; BARROS, V.M. de; PINTO, E.S.; BUDIÑO, F.E.L.; FRAGA, A.L.; HUAYNATE, R.A.R.; RUIZ, U. dos S. Níveis de zinco na dieta de leitões recém-desmamados sobre o perfil de parâmetros sangüíneos. Ciência Animal Brasileira, v.8, p.193-205, 2007.

BARBIN, D. Planejamento e análise estatística de experimentos agropecuários. Arapongas: Midas, 2003. 194p.

BEHMER, O.A.; TOLOSA, E.M.C. de; FREITAS NETO, A.G. de. Manual de técnicas para histologia normal e patológica. São Paulo: EDART, 1976. 241p.

BHATTARAI, S.; NIELSEN, J.P. Early indicators of iron deficiency in large piglets at weaning. Journal of Swine Health and Production, v.23, p.10-17, 2015.

BOAS, A.D.C.V.; BUDIÑO, F.E.L.; NETO, M.A.T.; SCHMIDT, A.; DADALT, J.C.; MONFERDINI, R.P.; SITANAKA, N.Y.; MORAES, J.E.; PIZZOLANTE, C.C. Organic acids in diets of weaned piglets: performance, digestibility and economical viability. Arquivo Brasileiro de Medicina Veterinária e Zootecnia, v.68, p.1015-1022, 2016. DOI: 10.1590/1678-4162-8501.

BRAZ, D.B.; COSTA L.B.; BERENCHTEIN, B.; ALMEIDA, V.V.; MIYADA, V.S. Acidificantes como alternativa aos antimicrobianos promotores do crescimento de leitões. Archivos de Zootecnia, v.60, p.745-756, 2011. DOI: 10.4321/S000405922011000300062 .
CHIQUIERI, J.; SOARES, R.T.R.N.; LYRA, M.S.; HURTADO NERY, V.L.; FONSECA, J.B. Ácidos orgânicos na alimentação de leitões desmamados. Archivos de Zootecnia, v.58, p.609-612, 2009. Supl.1.

ESLAMI, G.; TAHERI, S.; GOUDARZI, H.; ALAVI, S.; POURKAVEH, B. Comparison of the inhibitory effects of antibiotics with that of pistacchio skin extract on enteric bacteria. Archives of Clinical Infectious Diseases, v.9,p.e20692, 2014. DOI: 10.5812/archcid.20692.

HALAS, D.; HEO, J.M.; HANSEN, C.F.; KIM, J.C.; HAMPSON, D.J.; MULLAN, B.P.; PLUSKE, J.R. Organic acids, prebiotics and protein level as dietary tools to control the weaning transition and reduce post-weaning diarrhoea in piglets. CAB Reviews: Perspectives in Agriculture, Veterinary Science, Nutrition and Natural Resources, v.2, p.1-13, 2007. DOI: 10.1079/ PAVSNNR20072079.

HAMAD, F.B.; MUBOFU, E.B. Potential biological applications of bio-based anacardic acids and their derivatives. International Journal of Molecular Sciences, v.16, p.8569-8590, 2015. DOI: 10.3390/ijms16048569.

HOLLANDS, A.; CORRIDEN, R.; GYSLER, G.; DAHESH, S.; OLSON, J.; ALI, S.R.; KUNKEL, M.T.; LIN, A.E.; FORLI, S.; NEWTON, A.C.; KUMAR, G.B.; NAIR, B.G.; PERRY, J.J.P.; NIZET, V. Natural product anacardic acid from cashew nut shells stimulates neutrophil extracellular trap production and bactericidal activity. The Journal of Biological Chemistry, v.291, p.13964-13973, 2016. DOI: 10.1074/jbc.M115.695866.

KANEKO, J.J. Appendixes. In: KANEKO, J.J. (Ed.). Clinical biochemistry of domestic animals. $4^{\text {th }} \mathrm{ed}$. San Diego: Academic Press, 1989. p.877-901.

KOMMERA, S.K.; MATEO, R.D.; NEHER, F.J.; KIM, S.W. Phytobiotics and organic acids as potential alternatives to the use of antibiotics in nursery pig diets. Asian-Australasian Journal of Animal Sciences, v.19, p.1784-1789, 2006. DOI: 10.5713/ ajas.2006.1784.

LALLĖS, J.-P. Nutrition and gut health of the young pig around weaning: what news? Archiva Zootechnica, v.11, p.5-15, 2008.

LI, Z.; YI, G.; YIN, J.; SUN, P.; LI, D.; KNIGHT, C. Effects of organic acids on growth performance, gastrointestinal $\mathrm{pH}$, intestinal microbial populations and immune responses of weaned pigs. The Asian-Australasian Journal of Animal Science, v.21, p.252-261, 2008. DOI: 10.5713/ajas.2008.70089.

MUROI, H.; KUBO, I. Antibacterial activity of anacardic acid and totarol, alone and in combination with methicillin, against methicillin-resistant Staphylococcus aureus. Journal of Applied Bacteriology, v.80, p.387-394, 1996. DOI: 10.1111/j.13652672.1996.tb03233.x.

NARASIMHAN, B.; PANGHAL, A.; SINGH, N.; DAKHE, A.S. Eficiency of anacardic acid as preservative in tomato products. Journal of Food Processing and Preservation, v.32, p.600-609, 2008. DOI: 10.1111/j.1745-4549.2008.00201.x.

OETTING, L.L.; UTIYAMA, C.E.; GIANI, P.A.; RUIZ, U. dos S.; MIYADA, V.S. Efeitos de antimicrobianos e extratos vegetais sobre a microbiota intestinal e a freqüência de diarréia em leitões

Pesq. agropec. bras., Brasília, v.52, n.12, p.1253-1260, dez. 2017 DOI: 10.1590/S0100-204X2017001200014 
recém-desmamados. Revista Brasileira de Zootecnia, v.35, p.2013-2017, 2006. DOI: 10.1590/S1516-35982006000700019.

PAPATSIROS, V.G.; CHRISTODOULOPOULOS, G.; FILIPPOPOULOS, L.C. The use of organic acids in monogastric animals (swine and rabbits). Journal of Cell and Animal Biology, v.6, p.154-159, 2012. DOI: 10.5897/JCAB11.081.

PAPATSIROS, V.G.; TASSIS, P.D.; TZIKA, E.D.; PAPAIOANNOU, D.S.; PETRIDOU, E.; ALEXOPOULOS, C.; KYRIAKIS, S.C. Effect of benzoic acid and combination of benzoic acid with a probiotic containing Bacillus Cereus var. Toyoi in weaned pig nutrition. Polish Journal of Veterinary Sciences, v.14, p.117-125, 2011. DOI: 10.2478/v10181-011-0017-8.

PARAMASHIVAPPA, R.; PHANI KUMAR, P.; VITHAYATHIL, P.J.; RAO A.S. Novel method for isolation of major phenolic constituents from cashew (Anacardium occidentale L.) nut shell liquid. Journal of Agricultural and Food Chemistry, v.49, p.2548-2551, 2001. DOI: 10.1021/jf001222j.

PARTANEN, K.H.; MROZ, Z. Organic acids for performance enhancement in pig diets. Nutrition Research Reviews, v.12, p.117-145, 1999. DOI: 10.1079/095442299108728884.

PEDROSO, A.A.; OETTING, L.L.; UTIYAMA, C.E.; MENTEN, J.F.M.; LAMBAIS, M.R.; MIYADA, V.S. Variabilidade espacial da comunidade bacteriana intestinal de suínos suplementados com antibióticos ou extratos herbais. Revista Brasileira de Zootecnia, v.34, p.1225-1233, 2005. DOI: 10.1590/S151635982005000400018 .

ROBLES-HUAYNATE, R.A.; THOMAZ, M.C.; SANTANA, A.E.; MASSON, G.C.I.H.; AMORIM, A.B.; SILVA, S.Z.; RUIZ, U. do S.; WATANABE, P.H.; BUDIÑO, F.E.L. Probiótico em dietas de suínos sobre os parâmetros sanguíneos e digestibilidade de rações. Semina: Ciências Agrárias, v.35, p.1627-1636, 2014. DOI: $10.5433 / 1679-0359.2014 \mathrm{v} 35 \mathrm{n} 3 \mathrm{p} 1627$.

ROSTAGNO, H.S; (Ed.). Tabelas brasileiras para aves e suínos: composição de alimentos e exigências nutricionais. 3.ed. Viçosa: UFV/DZO, 2011. 186p.

SILVA, M.L.F.; LIMA, J.A. de F.; CANTARELLI, V. de S.; AMARAL, N. de O.; ZANGERÔNIMO, M.G.; FIALHO, E.T. Probiotics and antibiotics as additives for sows and piglets during nursery phase. Revista Brasileira de Zootecnia, v.39, p.24532459, 2010. DOI: 10.1590/S1516-35982010001100019.
SOTO, J.C.H.; OLIVEIRA, R.G. de; MENEGUETI, V.C.; SACCO, S.R. Policitemia e eritrocitose em animais domésticos. Revista Científica Eletrônica de Medicina Veterinária, ano VI, 2008.

SUIRYANRAYNA, M.V.A.N.; RAMANA, J.V. A review of the effects of dietary organic acids fed to swine. Journal of Animal Science and Biotechnology, v.6, p.1-11, 2015. DOI: 10.1186/ s40104-015-0042-z.

SUNG, B.; PANDEY, M.K.; AHN, K.S.; YI, T.; CHATURVEDI, M.M.; LIU, M.; AGGARWAL, B.B. Anacardic acid (6-nonadecyl salicylic acid), an inhibitor of histone acetyltransferase, suppresses expression of nuclear factor- $\kappa \mathrm{B}$-regulated gene products involved in cell survival, proliferation, invasion, and inflammation through inhibition of the inhibitory subunit of nuclear factor- $\kappa \mathrm{B} \alpha$ kinase, leading to potentiation of apoptosis. Blood, v.111, p.4880-4891, 2008. DOI: 10.1182/blood-2007-10-117994.

TREVISAN, M.T.S.; PFUNDSTEIN, B.; HAUBNER, R.; WÜRTELE, G.; SPIEGELHALDER, B.; BARTSCH, H.; OWEN, R.W. Characterization of alkyl phenols in cashew (Anacardium occidentale) products and assay of their antioxidant capacity. Food and Chemical Toxicology, v.44, p.188-197, 2006. DOI: 10.1016/j.fct.2005.06.012.

TUCCI, F.M.; THOMAZ, M.C.; NAKAGHI, L.S.O.; HANNAS, M.I.; SCANDOLERA, A.J.; BUDIÑO, F.E.L. Efeito da adição de agentes tróficos na dieta de leitões desmamados sobre a estrutura e ultraestrutura do intestino delgado e sobre o desempenho. Arquivo Brasileiro de Medicina Veterinária e Zootecnia, v.63, p.931-940, 2011. DOI: 10.1590/S0102-09352011000400019.

UTIYAMA, C.E.; OETTING, L.L.; GIANI, P.A.; RUIZ, U. dos S.; MIYADA, V.S. Efeitos de antimicrobianos, prebióticos, probióticos e extratos vegetais sobre a microbiota intestinal, a freqüência de diarréia e o desempenho de leitões recémdesmamados. Revista Brasileira de Zootecnia, v.35, p.23592367, 2006. DOI: 10.1590/S1516-35982006000800023.

WALSH, M.C.; SHOLLY, D.M.; HINSON, R.B.; SADDORIS, K.L.; SUTTON, A.L.; RADCLIFFE, J.S.; ODGAARD, R.; MURPHY, J.; RICHERT, B.T. Effects of water and diet acidification with and without antibiotics on weanling pig growth and microbial shedding. Journal of Animal Science, v.85, p.17991808, 2014. DOI: 10.2527/jas.2006-049. 